\title{
THE PRAGUE SPRING OF 1968 AND THE COSSACKS ANTI-SOVIETS GAMES OF TEENAGERS FROM ODESA
}

\section{Anatoliy Khromov}

PhD (History), head's assistant

The sectoral state archive of the Security Service of Ukraine

7, Street Zolotovoritskaya Str., Kyiv, 01061, Ukraine

hromov1985@ukr.net

In the article on the basis of uncovered documents of KGB from the funds of the Branch State Archive of the Security Service of Ukraine and the Archive of the temporary storage of the Office of the Security Service of Ukraine in the Odessa region is described the anti-Soviet action of Odessa teenagers. In particular, the question is about their leaflet that condemned the Soviet occupation of Czechoslovakia in 1968 (a photocopy of the leaflet is in the illustrations of the article). It is established that the guy who produced the leaflet in support of the Prague Spring of 1968, before that, had created together with friends a "secret" Cossack organization. The author of the article searched and found the main person involved in the archive-criminal case. The hero refused a public interview, did not want to supplement the article with his memories. He does not consider his act to be a real act of the hero. At the same time, this incident was one of the hundreds of such protests by Soviet citizens against the occupation of Czechoslovakia in 1968.

Keywords: Prague Spring, KGB, archives, Cossacks, Odesa.

Анатолій Хромов

Кандидат історичних наук, заступник директора Галузевий державний архів Служби безпеки України Вум. Золотоворітська, 7, Київ, 01061, Україна hromov1985@ukr.net

\section{ПРАЗЬКА ВЕСНА 1968 РОКУ Й АНТИРАДЯНСЬКІ ІГРИ} В КОЗАКІВ ОДЕСЫКИХ ПІДАІТКІВ

В статті, на основі розсекречених документів із фрондів Галузевого державного архіву Служби безпеки Украйни та Архіву тимчасового зберігання Управління Служби безпеки Украйни в Одеській області, описана антирадянська акиія одеських підлітків. Зокрема, мова йде про виготовлення ними листівки з засудженням радянської окупаиї Чехословаччини в 1968 р. (фотокопія листівки додається в ілюстраціях). Встановлено, що хлопець, який виготовив листівку на підтримку Празької весни 1968 р., до того разом з друзями створив "таємну" козацьку організацію.

Ключові слова: Празька весна, КДБ, архіви, козаки, Одеса.

В 2018 р. відзначається 50-річчя подій Празької весни. Народні протести січня-серпня 1968 р. проти радянського впливу в Чехословаччині та силове придушення реформ військами країн-членів Варшавського договору (операція "Дунай") викликали хвилю протестів та засудження політики Радянського Союзу в середовищі інтелігенції та представників інших верств населення. 
Ідеї Празької весни не тільки політизували радянське суспільство, але стали дієвим стимулом розвитку правозахисного та національних рухів, особливо в прикордонній УРСР [7, с. 104]. Серед населення Західних областей УРСР ширилися панічні настрої, радянські спецслужби збирали свідчення про засудження окупації Чехословаччини, навіть серед військового контингенту [6, с.15-17]. Вище партійне керівництво УРСР вживало заходів щодо блокування доступу населення до преси, яка висвітлювала життя українців в Чехословаччині, посилювало агітаційну та пропагандистську роботу [3, с. 37-54]. КДБ почало справжнє полювання на громадян, незгодних з політикою військового придушення чехословацьких реформ, та відкрило сотні кримінальних справ на мешканців різних регіонів України: викладачів ВУЗів та вчителів шкіл, військових, інженерів, робітників, студентів та навіть компартійних функціонерів. Один із найбільш показових списків репресованих українців у зв'язку з подіями Празької весни наводить дослідник В. Дмитрук [5, с. 298-312]. Були серед репресованих і одесити: незадоволення або навіть сумніви яких, щодо адекватності реакції керівництва країни на чехословацькі події 1968 р., кваліфікувались як антирадянська діяльність та приводили до тюремного ув'язнення. Серед них відомі правозахисники Н. Строката (Караванська), О. Різників, О. Притика, а також інші громадяни: аптекар А. Красножон, фізик П. Бутов [2].

Приморське місто Одеса постійно було під особливою увагою радянських спецслужб, а чехословацькі події 1968 р. мише посилили контроль КДБ щодо настроїв містян. Результати проведення спеціальних заходів свідчили про обізнаність та поінформованість одеситів щодо події Празької весни, зокрема в спецповідомленні від 09 квітня 1968 р. Голови КДБ при РМ УРСР В. Нікітченка в ЦК КПУ міститься витяг з приватного миста мешканця Праги Ю. Хари до учениці 9-го класу однієї з одеських шкіл. В ньому студент описує своїй подружці події, які називає "великою революцією" та побоюється (як виявияось небезпідставно) "...що ваші (радянські - А.X.) та німецькі (Східної Німеччини - А.Х.) війська знищать революції в крові... Якщо ваші війська прийдуть в Чехословаччину, багато студентів, і я перший, будуть воювати в партизанських загонах проти усіх, хто би хотів знищити нашу свободу". Адресант просить одеситку: "Я хотів би щоб ти про це говорила дуже довго i всім студентам. Наша свобода та демократія набагато старіше за вашу і ми не хочемо жодних вчителів..." [4, арк. 52]. В таких умовах одеське обласне управління КДБ посилює контроль за молоддю і скоро виходить на законспіровану антирадянську козацьку організацію одеських підмітків.

КАючовим фігурантом справи став 17-річний одесит Анатолій Авєрічєв [1], на нього наприкінці серпня 1968 р. гебісти завели кримінальну справу за ст. 187-1 Кримінального кодексу УРСР «Поширювання завідомо неправдивих вигадок, що порочать радянський державний і суспільний мад" із можливою санкцією позбавцення волі до трьох років (Малюнок 1). 


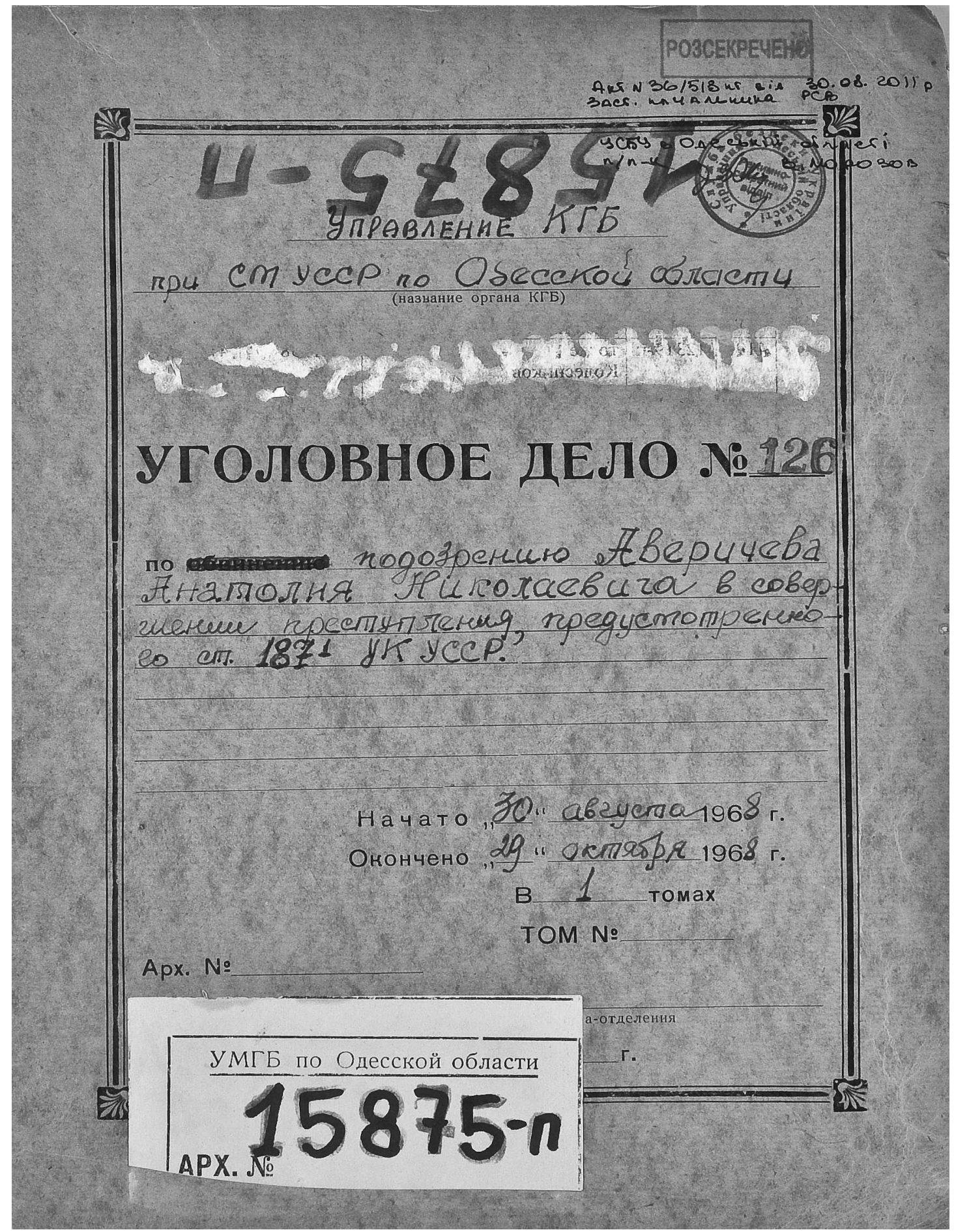

Малюнок 1. Архівно-кримінальна справа на Анатолія Авєрічєва. Архівний підрозділ УСБУ в Одесъкій області. - Ф. 4. - On. 1. - Спр. 15875-n.

на підтримку Празької весни: "Долой советских оккупантов. Да здравствует чехословатская революция". Зазначену $и$ истівку А. Авєрічєв написав великими мітерами, чорними чорнилами, на аркуші зошита в кмітинку та пізніше, на роботі, створив копіі на машині "ЕРА" (Малюнок №2). Крім того, сам підозрюваний та свідки, повідомили про факт попереднього виготовлення та знищення схожих мистівок з призивами до громадян СРСР протестувати проти введення військ в Чехословаччину [1, арк. 8, 9, 12]. 


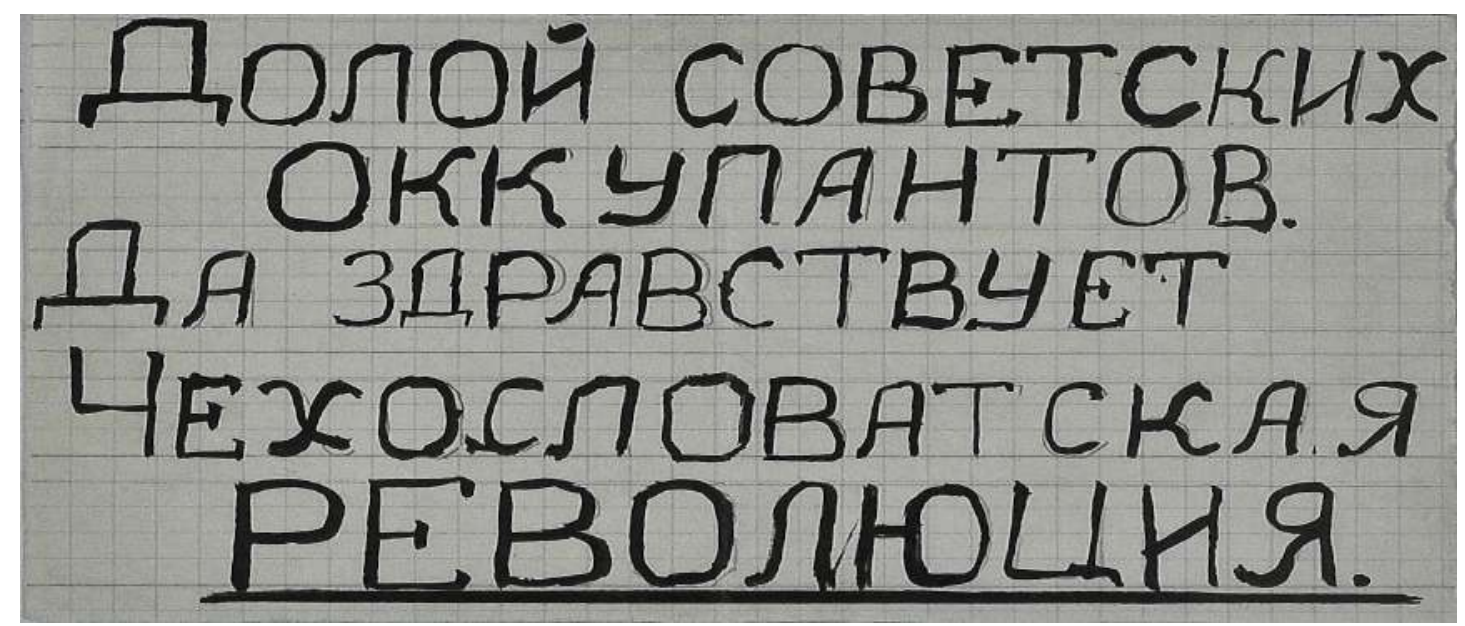

Малюнок 2. Архівно-кримінальна справа на Анатолія Авєрічєва.

Архівний підрозділ УСБУ в Одесъкій області. - Ф. 4. - On. 1. - Спр. 15875-n.

Разом з тим, матеріали архівно-кримінальної справи розкривають тло "антирадянської діяльності" Толі, а саме участь його та друзівпідлітків в "таємній козацькій організації». Архівна справа розкриває неймовірну, іноді фантастичну та трагікомічну життєву історію одеських підлітків, які, романтизуючи російську імперську традицію, медь не стали жертвами комуністичного тоталітарного режиму.

Мешканці центру Одеси, 17-річні Анатолій Авєрічєв та його друг Вадим, дружили декілька років, а в 1968 р. їм поталанило взяти участь у зйомках кінокартини "Служили два товарища". Як учасники масовки вони вперше приміряли однострої юнкерів та офіцерів Білої армії, та, судячи 3 наступних подій, захопились романтикою російської імперської військової історії. Друзі починають збирати відповідний історичний одяг, історичні пригодницькі книги, колекціонують дорадянські банкноти, ордени та медалі, навіть роздобули прапор Російської імперії, а також записують до щоденників пісні Володимира Висоцького (який, до речі, у згаданому фільмі, був виконавцем ромі білогвардійського поручника Брусєнцова). Разом з двоюрідною сестрою Вадима, 14-річною Тетяною, яка теж знімалась в масовці гімназисткою, вони створюють "таємну організацію" та починають грати в "12-й Донской казачий полк" (назва вірогідно була взята із роману М. Шолохова "Тихий Дон", місця служби головного герою твору Григорія Мєлєхова). Пізніше до них приєднались інші одеські підмітки - два Олександри 16 та 17 років. На таємних зібраннях учасники гри перевдягались в історичні однострої, чіпляли медалі та ордени, пили вино, курили сигари, грали на дитячому більярді, "сплачували" борги дорадянськими банкнотами, затверджували "військові чини" один одному: військовий старшина, хорунжий, осавуц і таке інше. Саме грою, а точніше бажанням вислужитися перед "військовим старшиною"

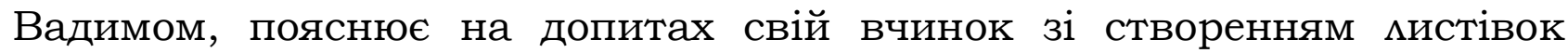
"хорунжий" Анатолій Авєрічєв. Важко встановити чи це було юнацьке захоплення історією, чи сміливий вчинок підлітка 3 подальшим 
обранням відповідної захисної поведінки. Якби там не було, 29 жовтня 1968 р., заступник прокурора Одеської області закрив кримінальну справу проти А. Аверічєва, через те, що неповнолітній визнав провину, мав позитивні характеристики з роботи, не представцяв загрози для суспільства та його вчинок не мав резонансу [1, арк. 125].

Ми зв'язалися з Анатолієм Авєрічєвим для того щоб взяти детальне інтерв'ю про мотиви його вчинку, перебіг слідства, подальшу життєву долю. На жаль, Анатолій Миколайович виказав бажання залишитися "в тіні». Аише зауважив, що не зважаючи на свідомість та вмотивованість своїх дій 3 виготовлення $и$ итівок 3 протестом проти окупації Чехословаччини в 1968 р., не вважає цей вчинок героїчним та гідним уваги суспільства.

Архівно-кримінальна справа Анатолія Авєрічєва, не зважаючи на козацьке тло "змочину" та закриття провадження прокурором на досудовому рівні, була типовою та доповнює собою сотні подібних справ відкритих радянськими органами держбезпеки проти громадян, які не підтримали окупацію Чехословаччини 1968 року. Вчинок одеського підлітка, завдяки відкриттю доступу до архівів КДБ в Україні, тепер може стати одним із фрагментів більш детальних досліджень 3 історії антирадянських рухів в Україні, Чехії та Словаччині.

\section{Джерема та мітература:}

1. Архівний підрозді^ УСБУ в Одеській області. - Ф. 4. - Оп. 1. - Спр. 15875-п. -128 арк.

2. Архівний підроздіц УСБУ в Одеській області. - Ф.4. - Оп.1. - Спр. 24994-п в $11 \mathrm{~T}$.

3. Бажан О. Суспільні настрої в Україні у ході чехословацької кризи 1968 року за донесеннями радянських спецслужб /О. Бажан// 3 архівів ВУЧК-ГПУНКВД-КГБ. - 2008. - №1/2 (30/31). - С. 37-54.

4. Галузевий державний архів СБУ. - Ф. 16. - Оп. 1. - Спр. 971. - 348 арк.

5. Дмитрук В. Незгодні: події 1968 р. в Чехословаччині крізь призму архівнослідчих справ КДБ УРСР/ В.І. Дмитрук // Історія України. Маловідомі імена, події, факти (Збірник статей). Вип. 34. - 2007. - С. 298-312.

6. Дмитрук В. "Празька весна" і Україна/ В. І. Дмитрук // 3 архівів ВУЧКГПУ-НКВД-КГБ. - 2008. - № 1/2 (30/31). - С. 7-37.

7. Дмитрук В. Україна не мовчала: Реакція українського суспільства на події 1968 р. в Чехословаччині. - К.: Інститут історії України НАН України, 2004. $314 \mathrm{c}$.

\section{References:}

1. Arxivny `j pidrozdil USBU v Odes`kij oblasti (Ukrayina) [Archival Department of the Security Service of Ukraine in the Odessa region (Ukraine)]. - F. 4. - Op. 1. Spr. 15875-p. - 128 ark. [in Russian].

2. Arxivny ${ }^{\circ}$ pidrozdil USBU v Odes` kij oblasti (Ukrayina) [Archival Department of the Security Service of Ukraine in the Odessa region (Ukraine)]. - F. 4. - Op. 1. Spr. 24994-p. [in Russian]. 
3. Bazhan, O., 2008. Suspil`ni nastroyi v Ukrayini u xodi chexoslovacz`koyi kry`zy` 1968 roku za donesennyamy` radyans`ky`x speczsluzhb. $Z$ arxiviv VUChKGPU-NKVD-KGB, 30/31, s.37-54. [in Ukrainian].

4. Galuzevy`j derzhavny`j arxiv SBU (Ukrayina) [Branch State Archive of Security Service of Ukraine (Ukraine)]. - F. 16. - Op. 1. - Spr. 971. - 348 ark. [in Russian]. 5. Dmy`truk, V., 2007. Nezgodni: podiyi 1968 r. v Chexoslovachchy`ni kriz' pry`zmu arxivno-slidchy`x sprav KDB URSR. Istoriya Ukrayiny: Malovidomi imena, podiyi, fakty, 34. - s. 298-312. [in Ukrainian].

6. Dmy`truk, V., 2008. "Praz`ka vesna" i Ukrayina. $Z$ arxiviv VUChK-GPU-NKVD$K G B, 30 / 31$, s. 7-37. [in Ukrainian].

7. Dmy`truk, V., 2004. Ukrayina ne movchala: Reakciya ukrayins`kogo suspil`stva na podiyi 1968 r. $v$ Chexoslovachchy $n i$. Kyiv: Insty tut istoriyi Ukrayiny NAN Ukrayiny'. [in Ukrainian].

\section{Пражская весна 1968 г. и антисоветские игры в казаков одесских подростков}

В статье, на основе рассекреченных документов из фондов Отраслевого государственного архива Службы безопасности Украины и Архива временного хранения Управления Службы безопасности Украины в Одесской области, описана антисоветская акиия одесских подростков. В частности, речь идет про изготовление ними листовки осуждаюшей советскую оккупаиию Чехословакии в 1968 году (фотокопия листовки представлена в иллюстраииях статьи). Установлено, ито парень, который изготовил листовку в поддержку Пражской весны 1968 г., до этого создал вместе с друзьями "тайную" казаикую организаиию.

Ключевые слова: Пражская весна, КГБ, архивы, казаки, Одесса.

Отримано: 09.09.2018 р. 